\title{
REMANENT MAGNETIZATION OF THE JOTNIAN SANDSTONE IN SATAKUNTA, SW-FINLAND
}

\author{
K. J. Neuvonen
}

Neuvonen, K. J. 1973: Remanent magnetization of the Jotnian sandstone in Satakunta, SW-Finland. Bull. Geol. Finland 45, 23-27

\begin{abstract}
Direction and intensity of remanent magnetization were measured on samples from a flat-laying Precambrian sandstone before and after heating at $400^{\circ} \mathrm{C}$. The direction revealed and the calculated pole position agree with those observed for dike rocks in SW-Finland. The origin of the magnetization is discussed.
\end{abstract}

K. J. Neuvonen, Institute of Geology, University of Turku, 20500 Turku 50, Finland.

\section{Introduction}

Two large areas of unmetamorphosed sedimentary deposits are known in the Finnish Precambrian. One is located in the northern part of Finland, near the town of Oulu and is known as the Muhos siltstone formation. The other is the Satakunta sandstone deposit in SW-Finland, north of the town of Turku.

Both sedimentary deposits occur in down-cast structural basins with horisontal or only very slightly tilted bedding. Natural exposures are almost lacking in the Muhos basin and are also rare in the Satakunta area. Laitakari (1925) listed slightly more than 20 places where sandstone has been encountered beneath glacial sediments. Many of these sites, however, are not suitable for collecting oriented samples since the sand- stone is met with in deep water wells. Jotnian sandstones indicate a long period of denudation. According to Simonen and Kouvo (1955) and Marttila (1969), the general character of the sedimentary sequence (arkose sandstone, siltstone, shale layers, current bedding etc.) suggests a floodplain piedmont facies. Sederholm (Eskola, 1963) called the Satakunta Jotnian sandstone the »oldest red sandstone» because of its most frequently deep red color. In Sweden, similar Precambrian sandstones are known in several places and they are considered to be of Jotnian age. Sandstone of this same Jotnian type has also been encountered west of Lake Onega in Soviet Karelia. An age of about 1300 M.y. has commonly been accepted for the Jotnian sediments, but no fully reliable age determination is yet available. 


\section{Samples}

Oriented core samples were taken at all the sites where exposed sandstone made drilling possible. Only seven such places were available, however, because of the thick quaternary sediments covering the sandstone deposit. Most of the samples were drilled vertically and at most localities double samples were collected. The cores with a diameter of $25 \mathrm{~mm}$ were cut into $20 \mathrm{~mm}$ long specimens. This gives a height to diameter ratio of $0.8: 1$ which is close to the optimum ratio 0.865 as suggested by Noltimier (1971). The mineralogy of the sandstone is quite simple. Quartz and potassium feldspar are the principal minerals with minor plagioclase and mica. Conglomeratic variations with granitic pebbles are not uncommon. Mica rich siltstone layers are met with in several places and also in eratic blocks.

The magnetization of the rock is carried by magnetite, hematite and poorly crystallized ironoxide (»limonite»). Magnetite occurs sparsely as small octahedrons and as tiny balls of evidently cosmic origin (Marttila, 1969). Hematite and "limonite» are met with as fine pigment in feldspars and in the matrix.

\section{Measurements}

The strength and direction of NRM was measured on the cut specimens with a four sonde flux- gate magnetometer (Oerstedmeter, Dr. Förster, Reutlingen, W-Germany). The magnetization of the sandstone is so weak, however, that this instrument failed to give reproducible readings, and a spinner magnetometer with fluxgate sondes was employed instead. This instrument was first used by Foster (1966). Table 1 lists the measurements made after a minor correction due to the slight tilt of the bedding observed at some of the sampling stations.

\section{Demagnetization}

After measurement of the NRM, all the specimens were partialy demagnetized by heating in an electric oven. The type of oven used was that described by Stephenson (1967). Pilot specimens were heated first to find out the temperature suitable for demagnetization. This procedure revealed a weak magnetic component which was wiped out at a temperature of about $350^{\circ} \mathrm{C}$. Consequently, the heating of the samples was performed at $400^{\circ} \mathrm{C}$ (Fig. 1). $\mathrm{Ni}-\mathrm{Cr}$ alloy winding and a fluxgate controlled feed back system guaranteed the homogenity and stability of the zero magnetic field of the specimen space (8-12 specimens) within \pm 2 gammas during the heating and cooling period (1$\left.1 \frac{1}{2} \mathrm{hrs}\right)$.

Table 2 gives the measured magnetization values after heating.

TABle 1.

Natural remanent magnetization of the Satakunta sandstone.

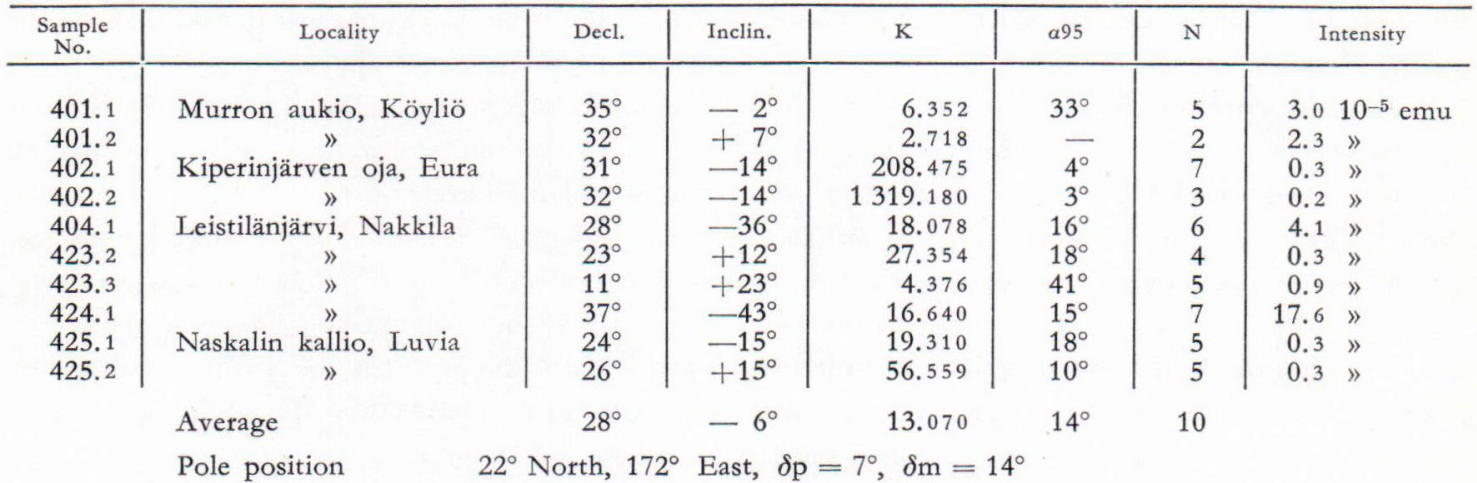




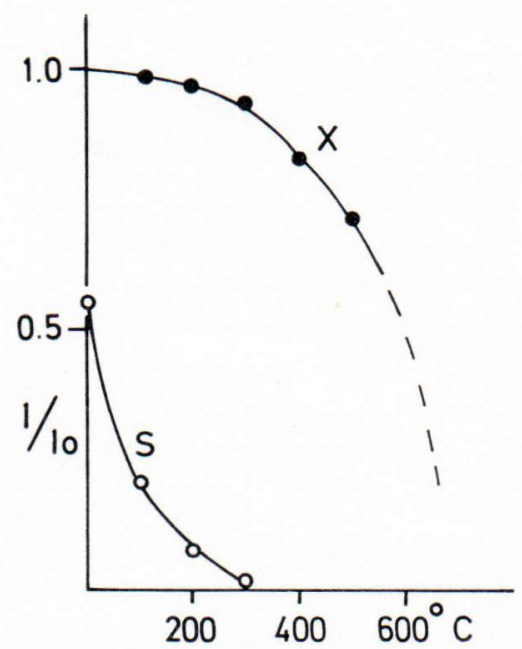

Fig. 1. Demagnetization curve of the pilot sample (402.1) $\mathrm{S}=$ unstable magnetization, $\mathrm{X}=$ stable magnetization.

Thermal cleaning changed the original directions of magnetization a great deal. This was as expected because of the weak viscous magnetization observed in the sedimentary samples concerned.

\section{Discussion}

Table 2 also gives the paleomagnetic pole position calculated from the mean magnetic direction measured on the demagnetized samples. This pole site $\left(180^{\circ}\right.$ East and $3^{\circ}$ North) is near to but slightly further south-east than the trend of the sites previously calculated on the base of Jotnian dolerites of Finland (Fig. 2). Jotnian olivine dolerite dikes (Pole No. 1) cut through the sandstone but the age difference is not supposed to be great.

The projection of the paleomagnetic pole on the wandering curve constructed (Fig. 2) lies close to the poles of the Vaasa and Satakunta dolerites (Neuvonen, 1970). This could mean that the age of the sandstone is also near to (but a little older than) that of the dolerites. This fact agrees with the field evidence since the sandstone is cut by the dolerite dikes. On the other hand, similar magnetic orientation met with in the sandstone and in the dolerite suite could also be interpretated as a result of the heating effect of the intrusive dikes on the sandstone. One of the samples measured (424.1) shows clear marks of this type of heating. Most of the samples collected were, however, far from the intrusive contacts.

There is yet one more explanation worth considering. Although the rock units concerned are of Precambrian age, the direction of magnetization measured could well be much younger due to remagnetization during prolonged deep burial. According to the present author, all the dating methods are affected by the elevated temperatures prevailing in the lower levels of the crust. High temperature means an increased speed of diffusion in the rock which causes the daughter

TABLE 2.

Remanent magnetization of the Satakunta sandstone after demagnetization at $400^{\circ} \mathrm{C}$.

\begin{tabular}{|c|c|c|c|c|c|c|c|}
\hline $\begin{array}{c}\text { Sample } \\
\text { No. }\end{array}$ & Decl. & Inclin. & K & $\alpha 95$ & $\mathrm{~N}$ & \multicolumn{2}{|c|}{ Intensity } \\
\hline 401.1 & $36^{\circ}$ & $-39^{\circ}$ & 69.771 & $11^{\circ}$ & 4 & 2.8 & $10^{-5} \mathrm{emu}$ \\
\hline 401.2 & $36^{\circ}$ & $-64^{\circ}$ & 6.137 & - & 2 & 2.1 & ") \\
\hline 402.1 & $23^{\circ}$ & $-41^{\circ}$ & 348.271 & $3.6^{\circ}$ & 6 & 0.3 & ») \\
\hline 402.2 & $28^{\circ}$ & $-50^{\circ}$ & 683.487 & 一 & 2 & 0.2 & $\gg$ \\
\hline 404.1 & $27^{\circ}$ & $-47^{\circ}$ & 136.521 & $6^{\circ}$ & 6 & 4.1 & $\gg$ \\
\hline 423.2 & $15^{\circ}$ & $-24^{\circ}$ & 16.884 & $23^{\circ}$ & 4 & 0.3 & $\ggg$ \\
\hline 423.3 & $13^{\circ}$ & $-12^{\circ}$ & 4.856 & $46^{\circ}$ & 4 & 0.9 & $\ggg$ \\
\hline 424.1 & $36^{\circ}$ & $-58^{\circ}$ & 81.562 & $8^{\circ}$ & 6 & 15.4 & » \\
\hline 425.1 & $18^{\circ}$ & $-43^{\circ}$ & 179.135 & $7^{\circ}$ & 4 & 0.3 & $»$ \\
\hline 425.2 & $21^{\circ}$ & $-34^{\circ}$ & 94.500 & $9^{\circ}$ & 4 & 0.2 & $»$ \\
\hline rerage & $24^{\circ}$ & $-41^{\circ}$ & 23.958 & $10^{\circ}$ & 10 & & \\
\hline
\end{tabular}

Pole position $\quad 3^{\circ}$ North, $180^{\circ}$ East, $\delta \mathrm{p}=8^{\circ}, \delta \mathrm{m}=12^{\circ}$ 


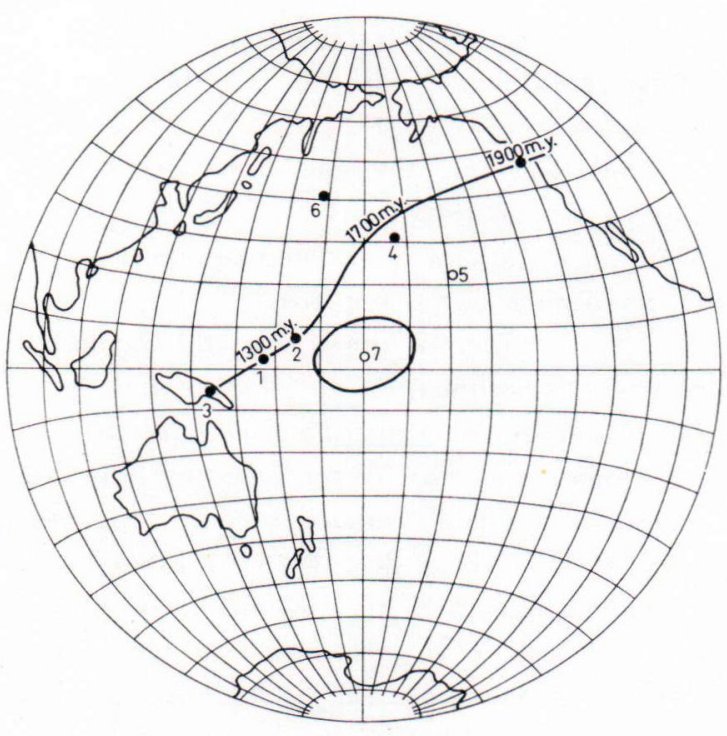

Fig. 2. Paleomagnetic pole positions.

1) Satakunta dolerite, 2) Vaasa dolerite, 3) Märket dolerite, 4) Föglö dolerite, 5) Kumlinge diabase, 6) Åva intrusions, and 7) Satakunta sandstone.

element to migrate out of a radioactive mineral thus finally bringing the radiometric »clock» to a stop (Neuvonen, 1960). Each radioactive mother-daughter pair has it's own temperature and depth, the so called "zeroline», at which it is no longer able to measure age. In principle, the same must be valid for magnetization and for magnetic age determination.

No magnetization has been recorded on rock units at depths at which the temperature is above the Curie point of magnetic minerals. This Curie point depth could be considered as the thermoremanent (TRM) zero line, the depth of which must vary due to the Curie temperatures of the different minerals and due to the geothermal gradient.

The rock becomes magnetized when it rises above the zero line and the direction of magnetization is subparallel with the local geomagnetic field. If the uplift of the block is rapid and the remanent magnetization stable enough the direction remains unchanged and it will be carried up to the exposed surface by denudation. This rock, if measured, gives the direction of the geomagnetic field of the time period at which it passed the zero line. The paleomagnetic pole so determined will also represent the time of the zero line passing and not that of the primary crystallization.

This direction corresponds, however, to some kind of theoretical maximum age. When the uplift and decrease in temperature are slow the remanent magnetization of the rock follows the change in the geomagnetic field. This goes on until the temperature is so low that the direction of magnetization stays put. This temperature defines a second magnetic zero line in the crust (VRM zero line). When weak magnetization is present this line can be on the exposed surface or may never be reached. During demagnetization the magnetization of the upper zero lines are destroyed and that of the lower zero lines revealed. In very rare cases, however, the direction of the pure TRM can be recovered.

The model described above can well be applied to the rocks in southwestern Finland. They have revealed stable magnetic directions which are fairly close together. This means that they all passed the (TRM) zero line during a relatively short period of time. Since the pole positions calculated fit well with the poles of the Paleozoic era in Europe (Storetvedt, 1968) it can be postulated that the passing of zero line occured during the Paleozoic time period. If this type of interpretation is correct it means that we can rarely find the "primary" TRM of rocks which have been buried for long periods of time deep down in the crust. This situation is most frequently met with in Precambrian and other old rocks. On the other hand, the information obtained by measuring the remanent magnetization of any rocks will always greatly depend on the thermal history of the rock and on the path and speed of the uplift. The role of paleomagnetic research in revealing these data can be of great importance.

Acknowledgements - The author would like to express his thanks for all the assistance received including the financial aid of the National Research Council for Science. 


\section{REFERENCES}

Eskola, Pentti (1963) The precambrian of Finland. The Geological systems, Kalervo Rankama ed., The Precambrian Vol. 1., New York-London-Sydney.

Foster, John H. (1966) A paleomagnetic spinner magnetometer using a fluxgate gradiometer. Earth and Planetary Science Letters 1, 463-466.

Laitakari, Aarne (1925) Über das Jotnische Gebiet von Satakunta. Fennia 45, No. 8.

Marttila, ERKki (1969) Satakunnan hiekkakiven sedimentaatio-olosuhteista. Thesis, Geological institute, University of Turku.

Neuvonen, K. J. (1960) The apparent age pattern of the crust. Compt. Rend. Soc. géol. Finlande 33, 445- 454.

- (1970) Paleomagnetism of the dike systems in Finland V. Remanent magnetization of the Åva intrusives. Bull. Geol. Soc. Finland 42, 101-107.
Noltimier, H. C. (1971) Magnetic rock cylinders with negligible shape anisotropy. Journ. Geoph. Research $76,4035-37$.

Simonen, Ahti and Kouvo, Olavi (1955) Sandstones in Finland. Bull. Geol. Comm. géol. Finlande 168, $57-88$.

Stephenson, A. (1967) Apparatus for thermal demagnetization by the progressive method. Methods in Palaeomagnetism. Collinsson, D. W., Creer, K. M., and Runcorn, S. K. ed., Amsterdam, 296-298.

Storetvedt, K. M. (1968) A synthesis of the paleozoic paleomagnetic data for Europe. Earth and Planetary Science Letters 3, 444-448.

Manuscript received, February 29, 1972. 